\title{
Interleukin-18 and NGAL in assessment of ESWL treatment safety in children with urolithiasis
}

\author{
KATARZYNA JOBS ${ }^{l}$, EWA STRAŻ-ŻEBROWSKA ${ }^{l}$, MAŁGORZATA PLACZYŃSKA ${ }^{l}$, \\ ROBERT ZDANOWSKI ${ }^{2}$, BOLESŁAW KALICKI ${ }^{1}$, SŁAWOMIR LEWICKI ${ }^{2}$, ANNA JUNG ${ }^{l}$ \\ ${ }^{1}$ Department of Pediatrics, Pediatric Nephrology and Allergology, Military Institute of Medicine, Warsaw, Poland \\ ${ }^{2}$ Department of Regenerative Medicine, Military Institute of Hygiene and Epidemiology, Warsaw, Poland
}

\begin{abstract}
Urolithiasis is recurrent chronic disease and a complex nephro-urological problem. Currently it is diagnosed in very young children, even infants in the first quarter of life. Until recently the main method of treatment for stones, which for various reasons did not pass spontaneously, was open surgery. At present, the main method replacing open surgery is extracorporeal shock wave lithotripsy (ESWL). Usefulness of common known indicators of the renal function to assess the safety of ESWL procedure is evaluated and verified. The basic markers are serum creatinine, cystatin $C$, urea, glomerular filtration rate and albuminuria assessment. Unfortunately all these methods show little sensitivity in the case of acute injury processes. There are efforts to use new biomarkers of renal tubular activity, which include among others interleukin 18 (IL-18) and neutrophil gelatinase-associated lipocalin (NGAL). The aim of the study was to assess the safety of ESWL by means of albumin to creatinine ratio, serum cystatin $C$ levels and concentration of two new markers: IL-18 and NGAL. Albumin to creatinine ratio $(p=0.28)$ and serum cystatin $C(p=0.63)$ collected before and 48 hours after ESWL did not show statistically significant differences. Similarly, both new markers (IL-18 and NGAL) showed no significant differences (urine IL-18 $p=0.31$; serum NGAL $p=0.11$; urine NGAL $p=0.29$ ). In conclusion, serum cystatin $C$ tests, urine albumin to creatinine ratio and new early markers of renal tubular injury confirmed the safety of the extracorporeal shock wave lithotripsy (ESWL) and show that the procedure does not cause any episode of acute renal injury.
\end{abstract}

Key words: urolithiasis, children, ESWL, safety, IL-18, NGAL.

(Centr Eur J Immunol 2014; 39 (3): 384-391)

\section{Introduction}

Urolithiasis is a systemic disease involving the formation of deposits in the urinary tract when an imbalance between crystallization promoters and inhibitors exists. It is recurrent, chronic disease and a complex nephro-urological problem. Currently, not only physicians of various specialties are interested in urolithiasis, but also specialists dealing with economics of public health. It is associated with an increasing number of patients. Epidemiological data indicate that urolithiasis affects $0.5-15 \%$ of adults [1] and $0.1-5.5 \%$ of children [2]. Because of such a large number of patients, urolithiasis fulfils criteria of civilization disease. The population study (National Health And Nutrition Examination Survey - NHANES III), conducted in the United States in 1988-1994, demonstrated an increased incidence of urolithiasis in a subpopulation of Caucasians aged $20-74$ years to $5.2 \%$ of population. It gives a $30 \%$ increase in the incidence of the disease compared to earlier NHANES research covering the years 1976-1988 [3]. In developed European countries, the proportion of patients with urolithiasis is $5-9 \%$, and the lowest incidence rate (1-5\%) occurs in the Far East countries [4, 5]. It is estimated that in Poland urolithiasis affects $2 \%$ of population [6]. There are no recent data concerning the Polish pediatric population. It is known, however, that children with urolithiasis represent $14.2 \%$ of urological and $2 \%$ of nephrological departments' patients [7]. In the past, urolithiasis was considered a disease of middle age. Currently it is diagnosed in an increasing number of young children, even infants in the first quarter of life.

Considering the recurrence of urolithiasis, it should be mentioned that, according to reports, up to $50 \%$ of patients without prophylaxis, will have another relapse within seven years. This proportion increased to $70 \%$ over 20 years of follow-up [8]. 
Urolithiasis can cause severe pain, promote recurrence of urinary tract infections, sometimes leads to the kidney failure. Therefore, early detection and treatment, followed by implementation of appropriate prevention are very important.

Until recently the primary method of treatment for stones, which for various reasons (size of a deposit, anatomical abnormalities in the urinary tract) did not spontaneously pass, was open surgery. Surgical management of urinary stones, especially recurrent ones, because of multiple renal parenchyma incision, caused permanent renal damage. Open surgery currently accounts for $1-5.4 \%$ of surgical techniques [9-11].

In most cases, deposits can be removed with the use of minimally invasive surgery. These methods include ESWL (extracorporeal shock wave lithotripsy), PCNL (percutaneous nephrolithotripsy) and URSL (ureteroscopic lithotripsy). Development of these methods has revolutionized the treatment of urolithiasis, and the constant technological progress increases their effectiveness and safety. The choice of therapy depends on medical indications according to the individual condition of the patient. It is essential to take into consideration the knowledge and skills of the urologist, as well as available equipment necessary to perform the procedure, when choosing the method.

Currently the main treatment method of urolithiasis in children is ESWL. It is at the same time highly effective and minimally invasive. The procedure uses concentrated sound waves generated outside of the body, which are focused on a stone in the urinary system, causing the stone to crush. Generated shock waves spread in an aqueous medium at a speed greater than the speed of the sound. They are characterized by a rapid growing phase and a slow disappearing phase. After focusing, waves cause significant tension within the stone, resulting in its disintegration by the compressive forces from the wave and tensile components formed by deflection from the opposite side $[12,13]$. Another mechanism caused by the shock wave is cavitation, which occurs due to a decrease in the pressure below the saturated vapor pressure of water. Cavitation bubbles penetrate pores and slits of the stone, causing a local increase in the temperature and pressure [14]. Depending on the mechanism of shockwave production, we divide lithotripters into: electrohydraulic, piezoelectric and electromagnetic.

Treatment of multiple stones requires several ESWL procedures.

In 40-60\% of patients, satisfactory results are achieved by ESWL therapy alone. The improvement of treatment effects is obtained by a combination of PCNL and ESWL (elimination of urinary deposits even in $85 \%$ of patients). Currently, large complex stones, which in the past were an indication for open surgery, are treated with a combination of less invasive methods: first PCNL and then ESWL [15-17]. In most cases, it becomes necessary to repeat the treatment with several ESWL procedures. Sometimes a large mass of stone needs placing the stent coiled at both ends (double $\mathrm{J}$ ) in the ureter, to ensure the passage of stone particles [18].

Contraindications for ESWL treatment include: pregnancy, coagulation disorders, abdominal aortic aneurysm, anatomical barriers preventing stone passage and current symptomatic urinary tract infection.

Most cases of urolithiasis are accompanied by a urinary tract infection. In the case of purulent nephritis with fever, it is necessary to control symptoms of the infection at first. When there is leukocyturia and significant bacteriuria, antibiotic treatment, based on antibiogram results, should be performed prior to the procedure and after it [12, 19, 20].

Possible complications after ESWL therapy ensue from two processes: firstly from the direct effect of the shock wave on the tissue and secondly, from the passage of stone particles in the urinary tract. The most common side effects include skin lesions (redness, bruising, petechiae, in extreme cases necrosis), swelling of the renal parenchyma, hematoma, hematuria, proteinuria, dilatation of the pelvicalyceal system, urinary retention, hydronephrosis.

Hematuria directly after ESWL treatment occurs in about $30 \%$ of patients, significantly less often we can see intraparenchymal bleeding, and the most dangerous complications, like perirenal or subcapsular hematoma, are very rare. The majority of adverse effects are transient [21-23].

The impact of the shock wave on the kidney is associated with its direct pressure phase. In CT and MRI scans, morphological changes within the renal parenchyma are found in 24-85\% of patients treated with ESWL [22, 24]. Small vessels damage cause ischemia and hypoxia of renal tissue [14].

Scar formation and hypertension are considered permanent complications of ESWL therapy. Both of these conditions have no proven causal process and require further observation and research. This is the reason for searching for methods which can picture early renal tissue impairment.

\section{Methods of monitoring renal function in urolithiasis}

In patients with urolithiasis there are potential factors that may cause kidney injury. These include urinary obstruction or retention, increased risk of infections and their consequences, chronic and recurrent nature of the disease. Invasive methods of treatment may have also a direct or long-term effect on renal function due to the treatment procedure itself or its complications. Therefore, apart from continuous improvement of diagnostic methods concerning metabolic processes leading to urolithiasis and optimization of treatment methods, standards for effective monitoring of the disease and treatment process are sought. Along 
with the development of laboratory techniques and improvement of knowledge about the processes taking place in kidneys, early markers of the renal function appeared. The task is to establish markers showing high sensitivity and specificity for renal injury. It is important for them to have population value, to be marked with cheap tests and to be noninvasive for humans.

In addition to that research, the usefulness of already known indicators of the renal function is evaluated and verified. The basic markers are serum creatinine, cystatin $\mathrm{C}$, urea and glomerular filtration rate. Another way to evaluate renal injury is to assess albuminuria. All these methods, however, are useful mainly for the evaluation of chronic renal failure, and show little sensitivity in acute injury processes. There are efforts to use new biomarkers of renal tubular activity to perform such an assessment. They include among others interleukin-18 (IL-18) and neutrophil gelatinase-associated lipocalin (NGAL).

Interleukin 18 is a proinflammatory cytokine of a molecular weight $18 \mathrm{kDa}$. It is processed from a $24 \mathrm{kDa}$ proform into an $18 \mathrm{kDa}$ mature form by caspase- 1 . The increased concentration of IL-18 occurs during the acute kidney injury caused by hypoxia, ischemia and proximal tubule cells exposure to nephrotoxins. Elevation of IL-18 level was not observed in cases when renal failure was associated with prerenal causes, chronic kidney disease and urinary tract infection [25]. Interleukin 18 level can be measured in urine and serum. Urine test is early, fast, accurate and cheap for detection of early renal injury. The sensitivity and specificity in the diagnosis of acute kidney injury is over $90 \%$, and we can observe its increase 24-48 hours ahead of the elevation of serum creatinine [25].

Neutrophil gelatinase-associated lipocalin is a protein of molecular weight $25 \mathrm{kDa}$, consisting of 179 amino acids connected to human neutrophil gelatinase and produced by neutrophil leukocytes. The lipocalins are proteins that bind small hydrophobic molecules and transport them between cells. They include siderophores which transport iron. Neutrophil gelatinase-associated lipocalin is involved in immune response, bacterial growth limitation, cell proliferation, differentiation and apoptosis processes. Neutrophil gelatinase-associated lipocalin limits bacterial growth by binding to bacterial siderophores and sequestrating iron [26]. In low concentrations it is present in many human tissues. In kidneys NGAL is mainly expressed in the loop of Henle and distal tubules. It is filtered in glomerulus and reabsorbed in proximal tubules. Under physiological conditions urinary NGAL excretion amounts to $15.5 \pm 15.3$ $\mathrm{mg} / \mathrm{g}$ of creatinine [27]. Neutrophil gelatinase-associated lipocalin level significantly increases a few hours after renal injury, as a result of activation of the gene for NGAL. Acute kidney injury (AKI) can be caused by renal ischaemia, sepsis or nephrotoxic agents such as, for example, contrast agents. In patients with AKI, plasma NGAL level increased tenfold and urinary NGAL level increased hundredfold [28]. NGAL is a sensitive marker of renal injury, correlated with serum creatinine but preceding its growth. It appears that expression of NGAL after exposure to a damaging agent is associated with its impact on the proliferation of new cells [29, 30]. NGAL has been investigated in several studies. Its increase was observed in the cases of acute kidney injury due to hypoxia which occurs during cardiac surgery with cardiopulmonary bypass, after radiological examinations with contrast and also after nephrotoxic effect of cytostatics [30].

\section{Aim of the study}

The aim of the study was to assess the safety of ESWL on the basis of albuminuria, serum cystatin $C$ levels and selected new markers of renal function: IL-18 and NGAL.

\section{Material and methods}

In 30 children aged 7 months to 17 years, mean 8 years, treated with lithotripsy, serum NGAL and cystatin C concentrations, albuminuria and urinary IL-18 and NGAL levels were measured.

Informed consent was obtained from the patient's parents and patients older than 16 years. The study was approved by the local Ethical Committee.

All patients eligible for the ESWL therapy were questioned about the outset of urolithiasis, family medical history, previous diagnosis and treatment, history of urinary tract infections and their diet. The study excluded patients with fever, elevated markers of inflammation and symptoms of active infection. Chronic diseases and medication that could affect the procedure, anesthesia or stone passage after treatment were taken into consideration.

In physical examination, special attention was paid to blood pressure and assessment of the genitourinary system. On the basis of ultrasonography, attention was drawn to the presence of anatomical defects which might have an impact on the ESWL procedure or might reduce its effectiveness (causing difficulties of passage of crushed stones).

In all children, within 48 hours before ESWL, complete blood counts with the number of platelets, serum markers of inflammation, parameters of renal function (creatinine, urea) and coagulogram were performed. Patients whose tests did not show any abnormalities were qualified for the procedure. In addition, urinalysis and urine culture were done to exclude the urinary tract infection. As part of the diagnostic imaging, ultrasound of the urinary tract and abdominal X-ray were performed. Thus, the indications for ESWL were verified, since, according to generally accepted criteria, deposit should be at least $4 \mathrm{~mm}$ in diameter.

All patients had neutrophil gelatinase-associated lipocalin concentration (NGAL) measured in serum and NGAL and interleukin-18 concentration (IL-18) in urine 
48 hours before treatment. Then, 2-4 hours after the ESWL procedure, a urine sample was collected to determine the level of NGAL and IL-18. Forty-eight hours after the ESWL procedure, serum and urine NGAL and urine IL18 concentrations were measured once again. Before treatment, serum cystatin $\mathrm{C}$ and urine albumin to creatinine ratio from an early morning sample were determined. The same parameters were re-measured 48 hours after the procedure.

NGAL concentration was measured using the Human Lipocalin-2/NGAL Immunoassay QUANTIKINE® R\&D Systems, Catalog Number DLCN20. Interleukin-18 concentration was determined with the Human IL-18 ELISA Kit MBL International Corporation.

The calculations and analysis were performed with the use of Statistica 10.1 software (StatSoft Co). The $\mathrm{p}$ value of $<0.05$ was considered significant. In the study, multivariate analysis dominated. This was analysis of repeated measures in the same patient. In order to analyze this type of data, univariate and multivariate analysis (ANOVA) with appropriate corrections (Friedman, Kendall, Wilks) or its equivalent non-parametric post-hoc tests were used. Percentage data were analyzed by $\chi^{2}$ test with its modifications, depending on subgroup sizes. In order to compare the mean values, Student's $t$-test or Mann-Whitney $\underline{\underline{U}}$ test were used. But to analyze paired samples which did not meet criteria of normality, the Wilcoxon test was chosen.

\section{Results}

The results of studied parameters in patients treated with ESWL are shown in Table 1.
Albumin to creatinine ratio and cystatin C levels measured before and 48 hours after the ESWL procedure did not show any statistically significant differences (Table 2).

The IL-18 and NGAL levels collected before and 2-4 hours and 48 hours after ESWL did not show any statistically significant differences (Table 3 ).

Renal function monitored with serum cystatin $\mathrm{C}$ and albumin to creatinine ratio did not deteriorate within 48 hours after ESWL. There was no kidney injury, either, as assessed by the level of the new early biomarkers of renal tubular damage: IL-18 and NGAL concentration measured 4 and 48 hours after the ESWL procedure.

\section{Discussion}

The ESWL is the method of choice in treatment of urolithiasis located in the upper urinary tract (kidneys and upper part of the ureter), especially in the case of deposits that are up to $2 \mathrm{~cm}$ in diameter. ESWL therapy has been known since the eighties of the last century. It was first introduced in children by Newman in 1986 [29]. Information obtained from observations and experience over two decades of performing ESWL provides a reliable evaluation of its effectiveness, as well as side effects caused by the procedure. While it is easy to estimate the effectiveness of the ESWL in terms of location of the stones, their number, size, and chemical composition, it is much more difficult to conduct studies to evaluate the safety of this method of treatment. It is due to the lack of sensitive and specific markers of kidney injury, which appears immediately after the deleterious effect and allows to predict and monitor possible late side effects. Estimation of safety of

Table 1. The results of studied parameters in patients treated with ESWL

\begin{tabular}{|c|c|c|c|c|c|c|}
\hline Parameter & $n$ & Mean & Median & Min & $\operatorname{Max}$ & SD \\
\hline ACR urine 1 & 28 & 0.12 & 0.03 & 0.01 & 1.3 & 0.26 \\
\hline cystatin C serum 1 & 26 & 0.83 & 0.80 & 0.57 & 1.2 & 0.16 \\
\hline NGAL 1 serum & 27 & 61405.8 & 58542 & 26600 & 146960 & 27795.6 \\
\hline NGAL 1 urine & 26 & 28973.4 & 12694.5 & 1690 & 311769 & 59941.9 \\
\hline IL-18 1 urine & 29 & 25.38 & 11.40 & 1.00 & 161.4 & 37.09 \\
\hline NGAL 2 urine & 27 & 18008.6 & 8719.0 & 1327.0 & 165699.0 & 32210.2 \\
\hline IL-18 2 urine & 27 & 21.38 & 9.10 & 0.00 & 207.0 & 40.29 \\
\hline NGAL 2 serum & 29 & 51491.6 & 42778 & 16224 & 109520 & 23805.3 \\
\hline NGAL 3 urine & 30 & 18679.2 & 14402.5 & 636.0 & 69159.0 & 14866.9 \\
\hline IL-18 3 urine & 27 & 75.56 & 17.00 & 2.50 & 625.60 & 165.92 \\
\hline ACR urine 3 & 27 & 0.09 & 0.04 & 0.00 & 0.5 & 0.12 \\
\hline cystatin C serum 3 & 27 & 0.81 & 0.76 & 0.56 & 1.2 & 0.15 \\
\hline
\end{tabular}


Table 2. Wilcoxon test results for parameters measured before and after lithotripsy

\begin{tabular}{lcc}
\hline Parameter & $\boldsymbol{n}$ & $\boldsymbol{p}$ \\
\hline ACR in urine before and after the procedure & 26 & NS (0.28) \\
\hline $\begin{array}{l}\text { Serum cystatin C before and after the } \\
\text { procedure }\end{array}$ & 23 & NS (0.63) \\
\hline Serum NGAL before and after the procedure & 27 & NS $(0.11)$
\end{tabular}

$\overline{A C R-a l b u m i n}$ to creatinine ratio; NGAL-neutrophil gelatinase-associated lipocalin

the ESWL method and its impact on renal parenchyma in pediatric patients is particularly relevant, as it affects the kidneys that are in the growth phase and are more susceptible to harmful factors. Additionally, it should be taken into consideration that children's kidneys have longer expected life time than kidneys of adults. During the child's growth phase, anatomical changes of the urinary tract are important, and so are possible infections or coexisting congenital defects that require surgical intervention. Drugs and diagnostic procedures are used in a repeated manner. This affects the complex nature of the problem and makes it difficult to define potentially harmful factors.

Most of the publications, which discuss the adverse effects of the ESWL method, estimate complications with the use of clinical symptoms and imaging studies. Authors take into consideration systemic symptoms (pain and fever), symptoms concerning the urinary tract (infection, urinary retention caused by the moving fragments of crushed stones, renal hematoma), abnormal urinalysis results (proteinuria, hematuria) and skin changes occurring sometimes in place where the shockwave passes through the skin. A lot of important information is provided by ultrasound and scintigraphy. In contrast, there are few works discussing postoperative assessment of the renal function at the cellular level.

Pathomechanism of sound waves impact on renal tissue is not entirely understood. Probably there is a transitional parenchymal damage, which however does not lead to permanent sequel. As a result of the ESWL procedure, hemorrhagic and ischemic changes are formed which has been the subject of research conducted by Mitterberger $e t$ al. The authors evaluated RI (resistive index) in the kidneys, using Doppler ultrasound (CDUS), flows in MRI (MRPI) and scintigraphy with a big-endothelin-1 (BIGET-1). It was shown that RI increased within $24 \mathrm{~h}$ after treatment and persisted longer only in older patients [30].

Interesting observations were presented by Hiros et al., who tested RI in each patient not only in the kidney treated with ESWL, but also in the untreated kidney. A transient increase in RI was observed in both kidneys, but in the kidney that was not exposed to ESWL, the increase in RI lasted less than 24 hours. It was probably due to secretion of vasoconstricting substances [31].
Table 3. Summary of mean values and ANOVA Friedman test results for the analyzed parameters measured at three time points. I - before ESWL; II - 2-4 hours after ESWL; III - 48 hours after ESWL

\begin{tabular}{lcccc}
\hline Parameter & I & II & III & $\begin{array}{c}\boldsymbol{p} \text { in ANOVA } \\
\text { test }\end{array}$ \\
\hline Urine NGAL & 28973.4 & 18008.6 & 18679.2 & NS $(0.29)$ \\
\hline Urine IL-18 & 25.38 & 21.38 & 75.56 & NS $(0.31)$ \\
\hline NGAL-neutrophil gelatinase-associated lipocalin; IL-18-interleukin-18
\end{tabular}

The safety assessment of shock wave generated extracorporeally to crush kidney stones, based on the similar parameters as in the presented study, performed among others by Villányi et al. (serum creatinine, serum urea, serum electrolytes, microalbuminuria) [32] and Szewczyk (creatinine and uric acid clearance, erythropoietin level, plasma renin activity, microalbuminuria, and levels of Tamm-Horsfall protein in urine) [33]. The results of these studies indicate that the ESWL method does not lead to permanent kidney damage.

Most of the studies assessing safety of ESWL treatment are based on renal scintigraphy. In the study conducted in Brazil, 18 children were observed for three years after the ESWL procedure. Urine culture, blood pressure, renal ultrasound and DMSA renal scintigraphy were evaluated. A significant change was observed only in one patient - there was a decrease in the treated kidney size with a reduction in its glomerular filtration rate, from the initial rate of $45 \%$, by $36 \%$ after 6 months of follow-up, to $32 \%$ after further half of the year. In other cases, within 12 months of observation, there was no hypertension, parenchymal hematoma or significant scarring in renal scintigraphy. Authors emphasize in conclusion that possible damage of renal parenchyma in the early period after treatment is a transient situation and resolves spontaneously in all cases [34].

Most of the studies that evaluate safety of the ESWL treatment refer to adults or older children. Therefore, there might be some doubts about the use of this method in the treatment of small children, up to 2 years of age. Each study conducted in the pediatric group provides very valuable data, because there is a potential risk of damage due to greater immaturity of kidneys. In the French urological center, a safety assessment of the ESWL method was made in a group of smallest patients. The study included 19 children aged 5-24 months. The basis of this evaluation, in addition to physical examination and imaging studies, was DMSA renal scintigraphy. Twenty-four hours before the ESWL therapy scintigraphy was performed, and then 6 months after the last ESWL procedure, a comparative DMSA scan was carried out. None of the patients had any signs of chronic injury of the kidneys [35]. 
Taking into account that ESWL treatment is a factor that could potentially cause severe and persistent changes in the kidneys, a study concerning the use of antioxidants was also conducted. Patients were divided into a control group and a group in which antioxidants were given before the ESWL procedure, in the second and eighth hour after the treatment and the group in which antioxidants were used in the same manner only once after the procedure. The evaluation of the renal tubular injury was based on an analysis of albumin in the urine and $\beta 2-$ microalbumin measured at time intervals. The authors of the study concluded that ESWL does not cause permanent damage, but on the other hand, it is a method in which there is a production of free radicals (in the mechanism of ischemia and disturbed reperfusion), and administration of antioxidants has a protective effect [36].

New markers of the renal function tested in evaluating the episodes of acute kidney injury (AKI), include biomarkers that have been used and studied for last few years, such as serum and urine neutrophil gelatinase-associated lipocalin (NGAL) and specific cytokines, especially IL-18 in urine. They are promising in an early detection of AKI, as well as predictors of its occurrence or in observation of transition of the acute process into chronic kidney disease [37].

Neutrophil gelatinase-associated lipocalin concentration increases rapidly within 2-3 hours after activation of the harmful agent. This protein is detectable in body fluids - in physiological conditions, its highest concentration was detected in saliva $320 \mathrm{ng} / \mathrm{ml}(96.0-881 \mathrm{ng} / \mathrm{ml})$, urine 9.94 $\mathrm{ng} / \mathrm{ml}(0.40-72 \mathrm{ng} / \mathrm{ml})$ and serum $119 \mathrm{ng} / \mathrm{ml}$ (42.0-177 ng/ $\mathrm{ml}$ ) (by R\&D System). In normal conditions, NGAL is present in human tissues in low concentrations, whereas during various pathological processes there is a significant increase in this protein in urine and serum. In the literature, we can find reports about patients hospitalized in the Intensive Care Unit with acute kidney injury. In this group, a 10-fold increase in plasma NGAL and 100-fold in urine was observed, which strongly correlated with the elevation of serum creatinine. Kidney biopsy of these patients showed an accumulation of immunoreactive NGAL in $50 \%$ of renal tubules [38]. In another study of children hospitalized for diarrhea, a significant increase in urine NGAL was observed in those patients, who developed AKI associated with hemolytic-uremic syndrome [39]. Neutrophil gelatinase-associated lipocalin is also used as a predictor of renal parenchymal damage after contrast administration for radiological examination (in contrast-induced nephropathy). Creatinine usually used to assess the renal function - increases in serum 48-72 hours after administration of the contrast, while tubular damage occurs much earlier when serum creatinine rises usually there is already $50 \%$ deterioration of the renal function [38].

Similarly to NGAL, IL-18, which is a potent proinflammatory cytokine of a molecular weight $18 \mathrm{kDa}$, ac- tivated from an inactive $24 \mathrm{kDa}$ form by caspase- 1 , is used to detect and predict many pathological processes, including kidney injury. Increase in IL-18 concentration occurs during the acute kidney injury caused by hypoxia, ischemia and exposure to nephrotoxins in the proximal tubule cells [40].

In the presented study, IL-18 levels tested in urine of the patients before and after the ESWL procedure were not significantly different.

Many works analyzing the usefulness of IL-18 stressed sensitivity of this marker. Interleukin 18 levels significantly increased in the process of acute renal allograft rejection compared with uncomplicated transplantation and with acute tubulointerstitial nephritis [40]. In patients suffering from systemic lupus erythematosus, concentration of IL-18 was significantly higher than in healthy people and it positively correlated with the severity of the disease. It can therefore be concluded that this cytokine might be a prognostic factor of renal parenchyma involvement in this disease and that it allows to identify patients whose kidneys are in danger to be damaged [41].

Very few studies that attempt to use new biomarkers of renal tubule damage in patients treated with the ESWL procedure can be found in the available literature.

In the conference materials from the 1st Meeting of the EAU Section of Urolithiasis (EULIS) in 2011, published in European Urology, Zekey monitoring potential injury in renal parenchyma after ESWL treatment by determining the concentration of NGAL on the first, second and seventh day after the procedure, found no differences in the levels of the evaluated parameters. They concluded that ESWL treatment does not cause an episode of acute renal failure [42]. This is consistent with the results of our research.

However, in the study presented at the $31^{\text {st }}$ Congress of the Société Internationale d'Urologie in 2011, a summary of which was published in Urology, Nomikos et al. found a rapid increase in the urine IL-18 and serum cystatin C concentration 6 hours after lithotripsy. The increase in urine IL-18 level preceded elevation of cystatin, but elevated values of the second parameter persisted longer, it was still observed 10 days after treatment. There was however no difference in the concentrations of NGAL measured before and after the procedure [43].

In the presented study there was no significant increase in cystatin $\mathrm{C}$ and albuminuria after lithotripsy procedures. There was also no significant rise of IL-18 and NGAL concentration after ESWL therapy, which suggests that, during the application of the shock wave used in the ESWL method, there is no acute injury to renal parenchyma.

Although observations about possible kidney injury by ESWL therapy are few and the procedure is considered safe and effective, the safety monitoring of this type of treatment seems to be still justifiable. The implementation of new biomarkers (NGAL, IL-18) offers new opportuni- 
ties to evaluate the renal function in patients treated with ESWL and confirms once again the safety of the procedure.

\section{Conclusions}

Serum cystatin $C$ tests, urine albumin to creatinine ratio and new early markers of renal tubular injury (IL-18, NGAL) confirmed the safety of the extracorporeal shock wave lithotripsy (ESWL) and show that the procedure did not cause any episode of acute renal injury in the examined group of children.

The authors would like to thank Dr Beata Jurkiewicz from the Surgery Department of the Children's Hospital in Dziekanów Leśny for her kind cooperation.

The authors declare no conflict of interest.

\section{References}

1. Iguchi M, Umekawa T, Katoh Y, et al. (1996): Prevalence of urolithiasis In Kaizuka city, Japanes epidemiologic study of urinary stones. Int J Urol 3: 175-179.

2. Miliner DS, Murphy ME (1993): Urolithiasis in pediatric patients. Mayo Clin Proceed 68: 241-248.

3. Stamatelon KK, Francis ME, Jonem CA, et al. (2003): Time trends in reported prevalence of kidney stones in the United States, 1976-1994. Kidney Int 63: 1817-1823.

4. Pyrah LN. Renal Calculus. Springer Verlag. Berlin Heidelberg, New York 1979.

5. Brzósko S, Myśliwiec M (2009): Kamica moczowa. In: Wielka Interna. Nefrologia. Myśliwiec M. (eds.). Medical Tribune Polska, Warszawa: 320-329.

6. Borówka A, Antoniewicz A, Rau T (1996): Sprawozdanie z Konferencji ,Mało inwazyjne metody leczenia w urologii”. Nowa Medycyna 2: 60-64.

7. Daszkiewicz E, Wyszyńska T (1975): Kamica układu moczowego. In: Choroby układu moczowego u dzieci. Wyszyńska T (ed.). PZWL, Warszawa: 148-152.

8. Kamińska A, Jung A, Piechota W, et al. (2000): Hipocytraturia u dzieci z kamicą nerkową. Pol Merk Lek 46: 181-182.

9. Roslan M, Zachalski W, Bagińska J, et al. (2009): Zabiegowe metody leczenia kamicy moczowej. Forum Nefrol 2: 196-201.

10. Seruga JW (1990): Surgical management of calculi. Semin Nephrol 10: 53-55.

11. Tiselius HG, Alken P, Buck C, et al. Guidelines on Urolithiasis. European Association of Urology. 2008. http://www.uroweb. org/fileadmin/user_upload/Guidelines/Urolithiasis.pdf.

12. Bar K, Szkodny A, Noga A, et al. (1992): Kruszenie kamieni moczowych falą uderzeniową wytwarzaną pozaustrojowo (ESWL) - zasada działania, wskazania, wyniki, powikłania. Przegl Lek 49: 129-130.

13. Borkowski A (1991): Nowe metody leczenia kamicy górnych dróg moczowych. Pol Przegl Chir 63: 69-73.

14. Borkowski A, Borówka A (1994): Nowe metody leczenia kamicy górnych dróg moczowych. PZWL, Warszawa.

15. Anderson PA, Norman RW, Award SA (1989): Extracorporeal shock wave lithotripsy experience with large renal calculi. J Endourol 3: 31-35.
16. Fuchs GJ, Chaussy CG (1987): Extracorporeal shock wave lithotripsy for staghorn stones: reassessment of our treatment strategy. J Urol 5: 237-240.

17. Kahnoski R, Lingeman J, Coury T, et al. (1986): Combined percutaneous and extracorporeal shock wave lithotripsy for staghorn calculi: an alternative to anatrophic nephrolithotomy. J Urol 135: 679-682.

18. Bierkens AF, Hendrix AJ, Lemmens WA, et al. (1991): Extracorporeal shock wave lithotripsy for large renal calculi: the role of ureteral stents. A randomized trial. J Urol 145: 699-702.

19. Borówka A (1992): ESWL - Kruszenie kamieni moczowych falami uderzeniowymi wyzwalanymi pozaustrojowo. Ultrason Pol 2: 25-39.

20. Borówka A Krzeski T, Judycki J, et al. (1989): Kruszenie kamieni nerkowych i moczo-wodowych falami wstrząsowymi wyzwalanymi pozaustrojowo - ESWL. Post Nauk Med 2: 125-133.

21. Bar K, Szkodny A, Szewczyk W, et al. (1992): Analiza powikłań po zabiegach ESWL. Urol Pol 45: 199-201.

22. Lingeman JE, Woods J, Toth PD, et al. (1989): The role of lithotripsy and its side effects. J Urol 141: 739-797.

23. Picramenos D, Deliveliotis C, Alexopoulou K, et al. (1996): Extracorporeal shock wave lithotripsy for renal stones in children. Urol Inter 56: 86-90.

24. Szewczyk W, Nowak A, Szkodny G (1991): Próba oceny czynnościowej i morfologicznej nerki u chorych, u których rozbijano kamienie nerkowe falą uderzeniową generową pozaustrojowo (ESWL). Urol Pol 44: 96-192.

25. Lisowska-Myjak B (2010): Laboratoryjne wskaźniki ostrego uszkodzenia nerek oznaczane w moczu i w surowicy. Forum Nefrol 3: 71-81.

26. Al-Ismaili Z, Palijan A, Zappitelli M (2011): Biomarkers of acute kidney injury in children: Discovery, evaluation and clinical application. Pediatr Nephrol 26: 29-40.

27. Jung A, Jobs K, Żuber J (2011): Biomarkery uszkodzenia miąższu nerek. Ped Med Rodz 7: 4-14.

28. Trof RJ, Di Maggio F, Leemreis J (2006): Biomarkers of acute renal injury and renal failure. Shock 26: 245-253.

29. Newman DM, Coutry T, Lingeman JE, et al. (1986): Extracorporeal Srock wale lithotripsy experience in children. J Urol 136: 238-40.

30. Mitterberger M, Pinggera GM, Neururer R, et al. (2008): Multimodal evaluation of renal perfusional changes due to extracorporeal shock wave lithotripsy. BJU Int 101: 731-735.

31. Hiros M, Selimovic M, Spahovic H, Sadovic S (2009): Effects of extracorporeal shockwave lithotripsy on renal vasculature and renal resistive index (RI). Med Arh 63: 143-145.

32. Villányi KK, Székely JG, Farkas LM, et al. (2001): Shortterm changes in renal function after extracorporeal shock wave lithotripsy in children. J Urol 166: 222-224.

33. Szewczyk W. Wpływ zabiegu rozbijania kamienia nerkowego falami uderzeniowymi (ESWL) na czynność wydalniczą i wewnątrzwydzielniczą jedynej nerki. Śląska Akademia Medyczna, Katowice 1999.

34. Reis LO, Zani EL, Ikari O, et al. (2010): Extracorporeal lithotripsy in children. The efficacy and long-termal evaluation of renal parenchyma demage by $99 \mathrm{mTc}-\mathrm{DMSA}$ scintigraphy. Actas Urol Esp 34: 78-81.

35. Lottmann HB, Archambaud F, Traxer O, et al. (2000): The efficacy and parenchyma consequences of extracorporeal Srock wale lithotripsy in infants. BJU Int 85: 311-315. 
36. Al-Awadi KA, Kehinde EO, Loutfi I, et al. (2008): Treatment of renal calculi by lithotripsy: minimizing short-term shock wave induced renal damage by using antioxidants. Urol Res 36: $51-60$

37. Mori K, Lee HT, Rapaport D, et al. (2005): Endocytic delivery of lipocalin-siderophorin-iron complex rescues the kidney from ischemia-reperfusion injury. J Clin Invest 15: 442-449.

38. Małyszko J (2008): NGAL jako troponina w nefrologii. In: 8 Katowickie Seminarium „Postępy w nefrologii i nadciśnieniu tętniczym”. Więcek A (red.). Katowice: 50-63.

39. Trachtman H, Christem E, Cnaan A, et al. (2006): Neutrophil gelatinase-associated lipocalin in D+HUS: a novel marker of acute kidney injury in critically ill children. Pediatr Nephrol 21: 989-994.

40. Striz I, Krasna E, Honsova E, et al. (2005): Interleukin 18 (IL-18) upregulation in acute rejection of kidney allograft. Immunol Lett 99: 30-35.

41. Calvani N, Tucci M, Richards HB, et al. (2005): Th1 cytokines In the pathogenesis of lupus nephritis; the role of IL-18. Autoimmun Rev 4: 542-548.

42. Zekey F, Ates F, Soydan H, et al. (2010): Monitoring of potential damage, occurred by ESWL in the kidney, with NGAL (neutrophil gelatinase associated lipocalin). Eur Urol Suppl 10: 481-481.

43. Nomikos M, Kardakos I, Kalikaki A, et al. (2011): Interleukin-18 and N-GAL levels as biomarkers of inflammatory response after extracorporeal shock wave lithotripsy. Urology 78: S107-S108. 